\title{
42.
}

612.185

\section{Acetylcholin ノ血管作用二關スル研究補遗}

\author{
岡山整科大學生理學数室 (主任生沼敉授)
}

醫士學士尾皆忠

總序

近來 O. Loewi1) 及ビ H. H. Dale?)一派 =(化ッ

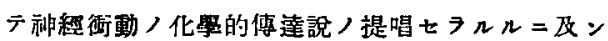

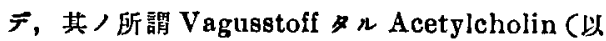
下 Ach. 略記 ス)/血管作用ニ關シテモ亦烀检

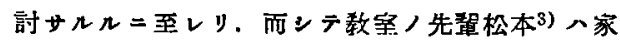

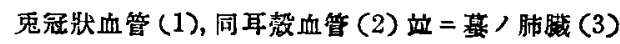
及ビ㷋肢血管 (4) =就灌流宽䮑习行七,Ach.八 溫血動物二於ケル前 2 者二對ン捗張作用 7 ，冾血 動物:於ケ几㣪者二龂シ收縮作用习有スルコトタ 報告ン，區々相岐レタル先人ノ業續ニ徽ンテ其

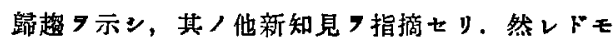
斯ク/如クAch. /血管作用ガ溫血動物卜冾血動 物ト二於テ相異 $コ$ 觀ラレ，珠ニ末梢血管二對スれ



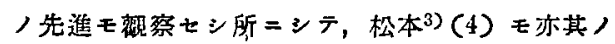
理由ニ關ンテハ未タ明白ナラズトセリ。然り而ン


法二化几モ/多ク，斯力几條件二於テへ，血管中 樞卜ノ進斷, 循環血液卜篧流液卜八間二於ヶ几組

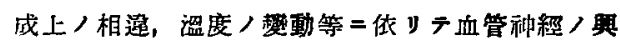

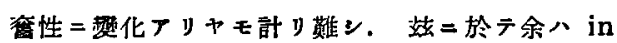
vivo =於ケルAch. /血管作用, 宣相箱七知 7

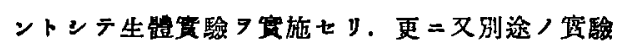

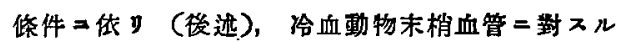

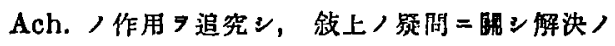



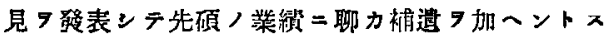
几次第ナり.

\section{第 1 編}

\section{1, 2 溫血動物血管二對スル Acetylcholin}

\section{，人作用}

\section{第1章 Acetylchólin /家鬼耳殼 血管二對スル作用二就テ}

第 1 節 緒 言

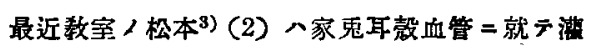

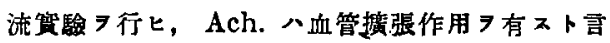
ールハ總序＝於テ选ベンガ如ン，依ッテ余八

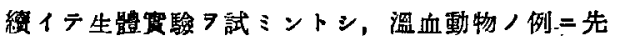
ッ家鬼习選ヒ，其/耳款皮庙/溫度 9 湘定シテ

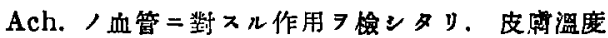

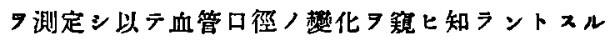

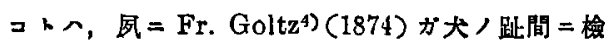
溫器

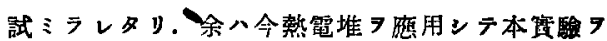
透行セリ。

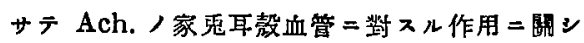

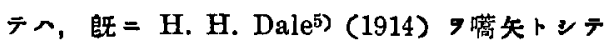

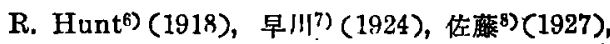
N. Necheles, R. Frank, W. Kaje, \& E. Rosen$\operatorname{man}^{91}$ (1936) 等，研究ア甲，就中摆 y R. Hunt

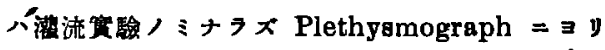


Ach. ノ血管壦張作用 9 報ズとドモ，其ノ他何レモ 灌流萲臹ニンテ， H. H. Dalé, N. Nccheles 等共

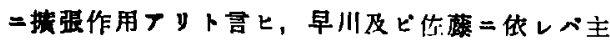

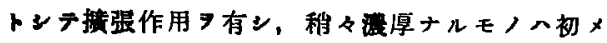

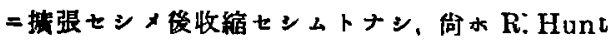

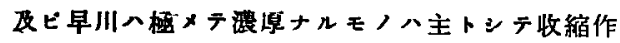
用习有スト壱ーリ。

$\therefore$ 第 2 節 宾驗方法

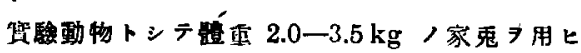

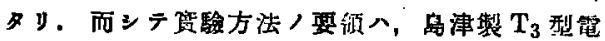

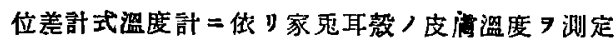
シ,以テ Ach. ガ該部血曾=及ボス作用 $=ョ ッ テ$

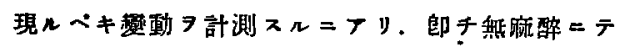

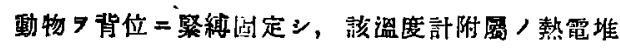

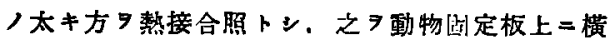

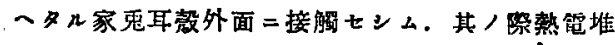

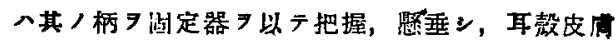
面卜電堆尖端トノ接合

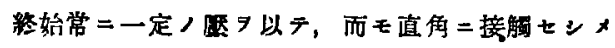

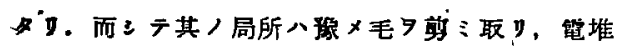
尖端

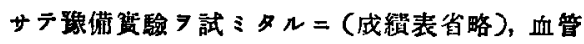

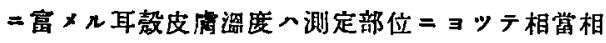
䢔フリタルラ以テ，比較的高溫ニンテ而モ血管反

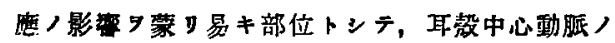
分枝スル㢸隘部

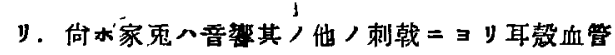

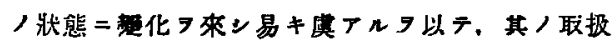
ン八極メテ靜肅萴重

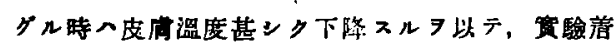

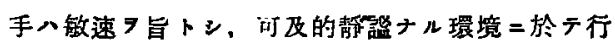

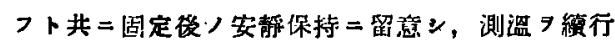
ンッッ該皮底溫ノ榤動著ンカラザル一定時期二被

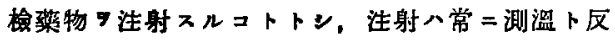

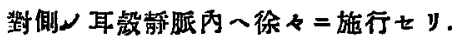

使用藥物及上゙其，使用法： R. Hunt ${ }^{6)}, \mathrm{H} . \mathrm{H}$. Dule ${ }^{\text {3 }}$, H. H. Dale \& A. N. Richardo ${ }^{10}$ 等八單

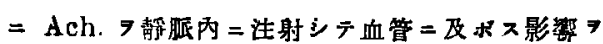
傕察セルモ，余へCholinesterase，作用 7 抑 制ン且 Ach.八作用

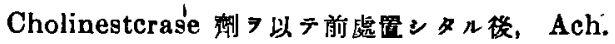
ヨ浩射スルコトトセリ．䬣手抗 Cholinesterase

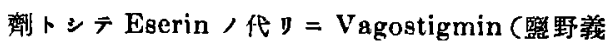

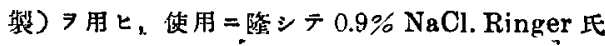
液二適宣稀裸七り.Ach. 一 Acetylcholinchlorid

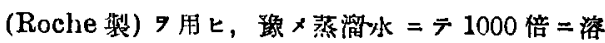
解レ堷色篦に入レテ水空 $\left(\mathrm{ca} .3^{\circ} \mathrm{C}\right) 3=$ 貯へ置キ。 用二臨ミテ同上 Ringer氐夜ニ稀釋シテ用ヒタ yＡtropin 八局方「硫酸厂トロピン」ヨ用上同上

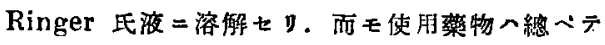

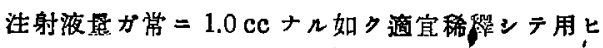
\$1).

第 3 節 贺驗成結

$$
\begin{gathered}
\text { 第1項 Vagostigmin ノ作用及ビ } \\
\text { Vagostigmin } \text { 以前處 } \\
\text { 置シタル場合=於ケル Ace- } \\
\text { tylcholin ノ作用 }
\end{gathered}
$$

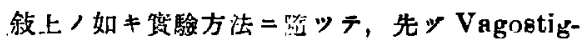
min (以下 Vst. ト略記 ᄉ) $0.005 \mathrm{mg}$. pro kg 注射

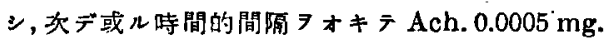
prokg 注射七り. 而ンテ注射䦎始ト共=Stop

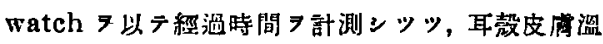
度/動 7 测定七リ。其，成績第 1 表(次頁)， 如上.

以上, 中, 例 1 一例 3 八冬季, 例 4一例 8 人而

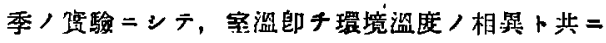

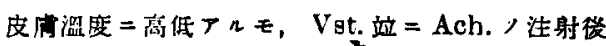
夫々ノ場合概シテ2 2 分一 3 分ニシテ該皮虚溫度， 上年习硯ラレタリ。但シ動物個や二依り，或八各 例二於二動物传定後，血管通動狀態又環境溫度， 相異等二低 $\boldsymbol{y}$ ，其/程度一定セザルモ，該皮成溫 度上昇ノ傾向アルコト明カナリ，而ンテ皮府滥度

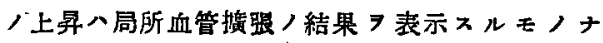

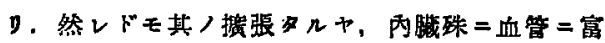


第 1 表

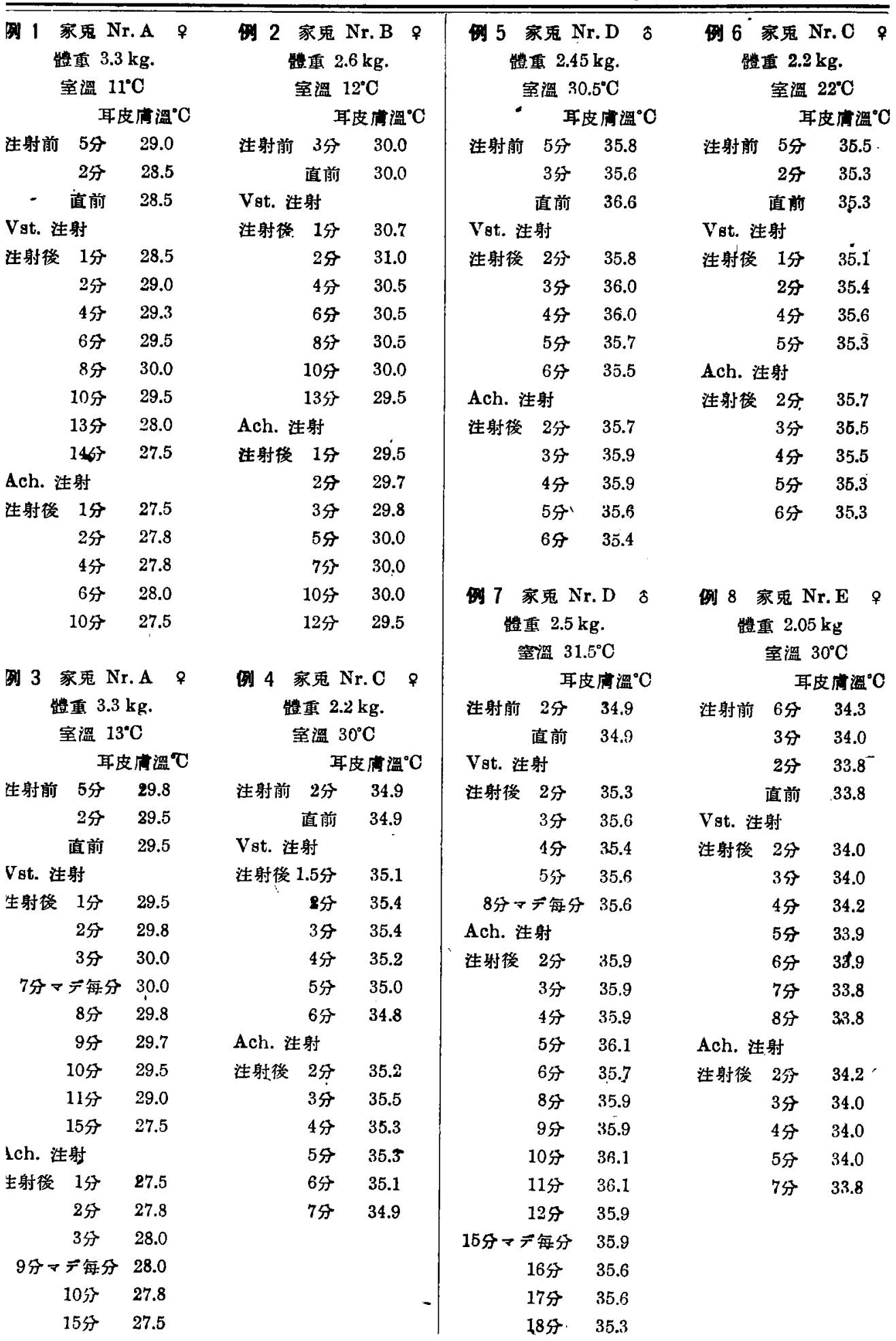




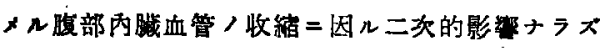
ヤトノ照念ナキニシモ非ナル

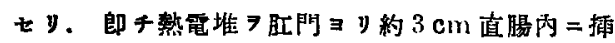

スシテ測溫シッッ，前卜同用量，Vat.立 $=$ Ach. 注射 7 試ミタル

\section{第 2 表}

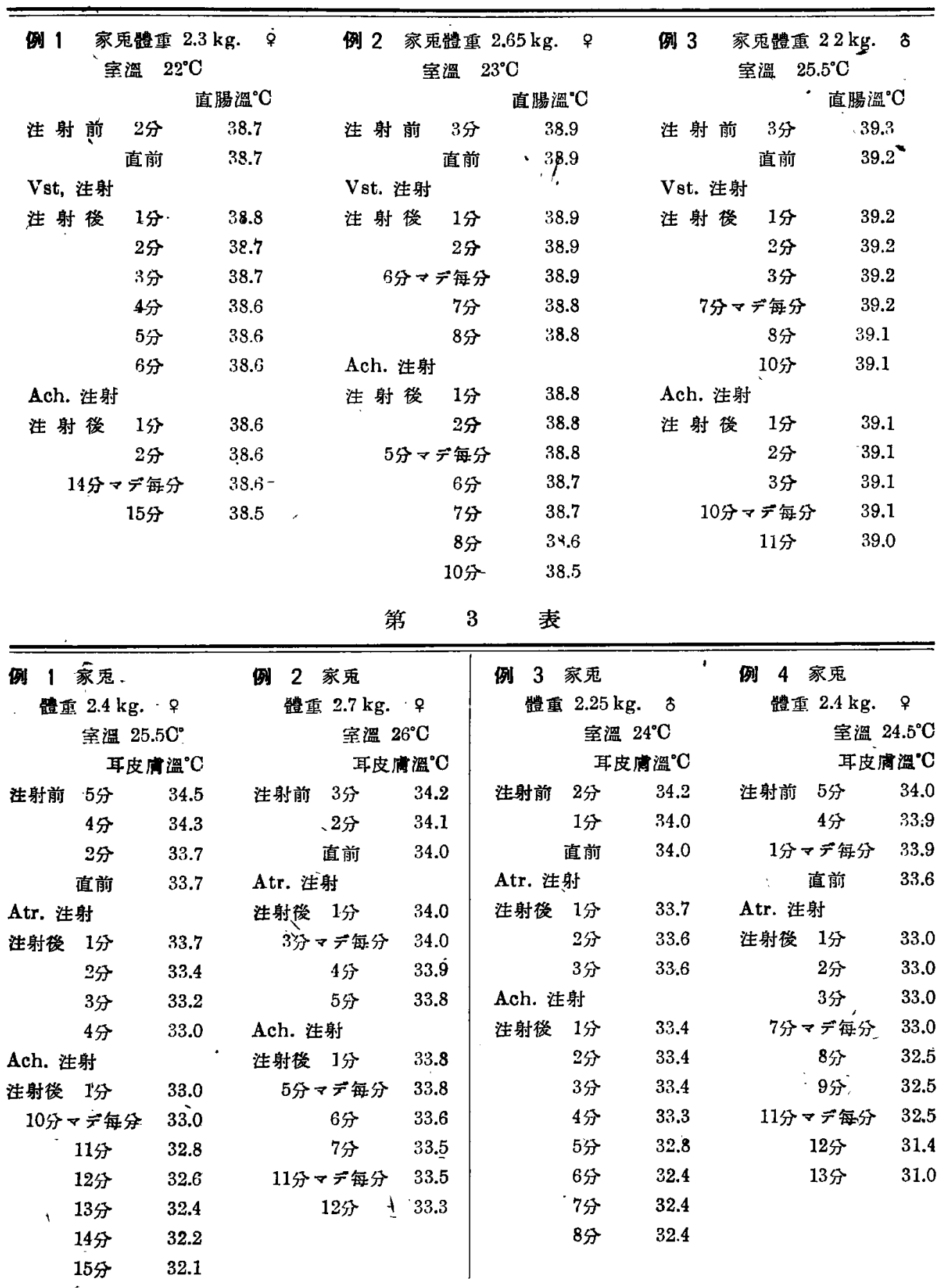




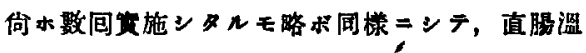

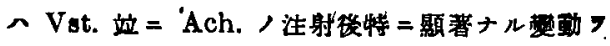

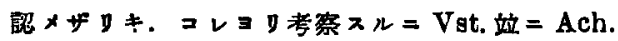

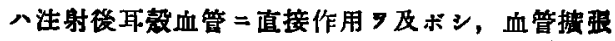
ノ結果局所ノ皮成䀀度上界フ示シタルモノナルベ シ. 而シテ Vst. 注射挠=現ヘルル血管/反㦄へ 之二化ッテ生體內二生理的二生シタ几 Ach. / 影 整=ヨルモノト思惟セラル。

第 2 項 嫄 $\times$ Atropin 7 以テ配シタ ル場合ニ於とル Acetylcholin ノ.作用

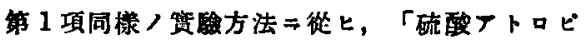
ン」 $71.0 \mathrm{mg}$ prokg 泩射シタ几後, Ach. 0.0005

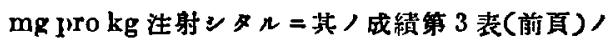
如ン.

郎チAtropin 7 以テ前處置施ンタル啳;Ach. フ注射スル＝第1項，場合二見ラレタルガ如キ皮



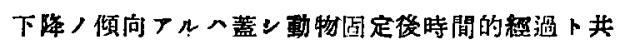
二自然的冷却 7 來

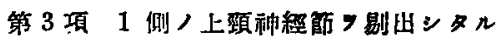

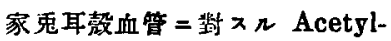
cholin / 作用

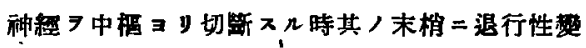
性 9 來 ス八, I. I. Tuckett ${ }^{11}$ ) =依レベ動物及 ビ动經ノ種類 $=$ ヨリ多少ノ差晎厂ルモ手術後約 5-12 日ナリト言ヘレ，血管運動袖虂二於テハ Iapinsky ${ }^{12)}$ 八 1 远乃至 3 造間, H. H. Dale \& A. N. Richards ${ }^{10)}$ 八2㥜間乃至夫レ以上ナyト 言一リ. サテ支配神縃 7 切斷シ共ノ末梢 $=$ 退行性 禁性ラ゙來サンメタ几血管二對ス几 Ach. ，作用亏

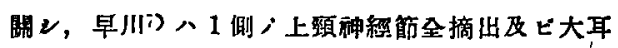

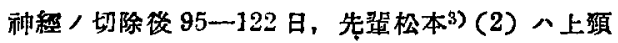

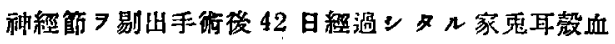
管二就キ，何レモKrawkow-Pissemski E法灌流 筫驗 7 行七，Ach. /血管摭镸作用へ依然トシテ

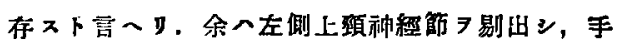

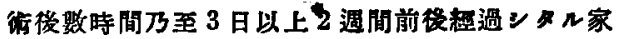
鬼 $=$ 就

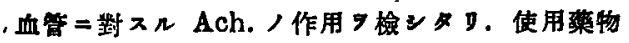

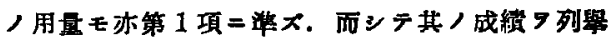
セン = 第 4 表 (狄頁) /如ン.

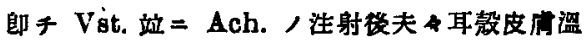


フルモ，摡ネ注射媵 2 分一3 分ニンテ溫度/上昇

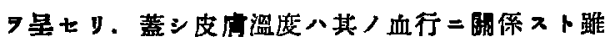

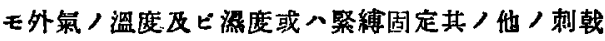

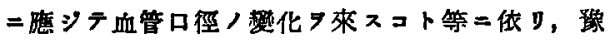

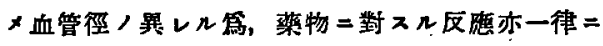
現レザリンモノノ如ン. 殊二剔出當日八手術㑡耳.

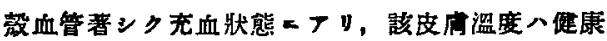

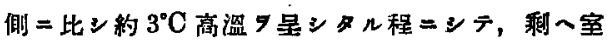

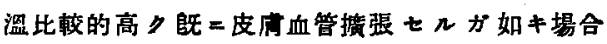

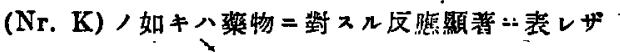
$\boldsymbol{y}$ キ. 次テ其ノ充血狀態稍々減退ンタ几很後第 3 日 $=八$ 注射後明確 $=$ 皮虑溫度 的效果 7 鹤ラレタy. 一其，侵手術㑡血管，充血八

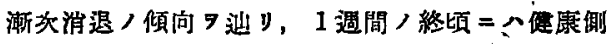

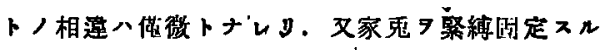
時八通例耳役血管怒镸充血 7 呈ス几モ/ナルモ， 其ノ後余が察驗

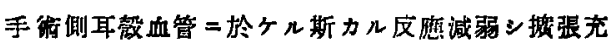
血スルモ健康側二於ヶルヨりモ其，消退比䡆的速

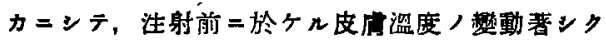

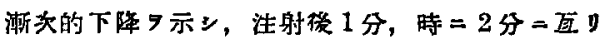



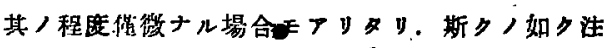


Ŕinger 氏液同量注射ンタ几對照例二於テモ認メ

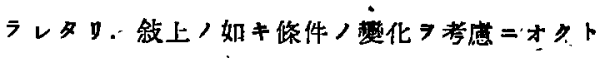
”，之等／場合二毛注射藥物／效果八事寡上可成 リノ程度二血管控張的二作用ンタ几モノト解ン得

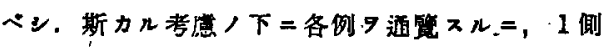

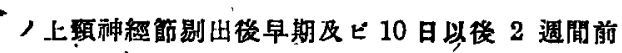


第 4 表

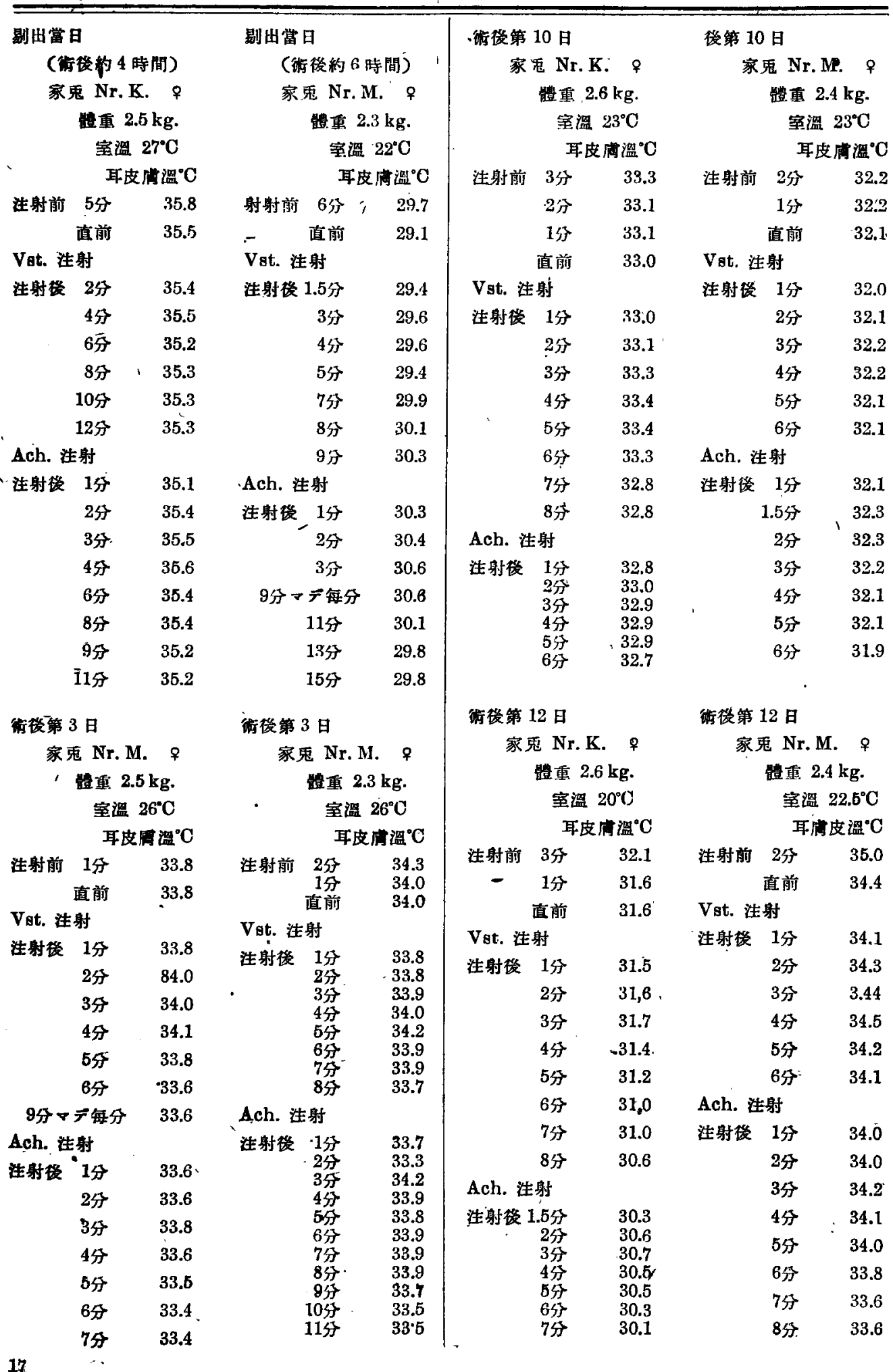


得楼第 14 日

家兔 Nr. K. $q$

踖重 $9.65 \mathrm{~kg}$.

- 室湓 $21.6^{\circ} \mathrm{C}$

耳皮府温 ${ }^{\circ} \mathrm{C}$

注射前 4 分 $33.2^{\circ}$

2分 32.9

直前 32.8

V at. 注射

注射㷋 1 分 33.0

$\begin{array}{rr}\text { 2分 } & 33.1 \\ \text { 3分 } & 33.0 \\ \text { 4分 } & 33.0 \\ \text { 5分 } & 32.6 \\ \text { 6分 } & 32.3 \\ \text { 7分 } & 32.1\end{array}$

Ach. 注射

注射棬 1 分， 32.0

2分 32.1

3分 32.1

4分 31.9

5分 31.9

6分 31.8

7分 31.6

街媵第 15 日

家鬼 Nr. K. 17

鰽重 $2.65 \mathrm{~kg}$.

室洫 $21.5^{\circ} \mathrm{C}$

耳皮庙溫” $\mathrm{C}$

注射前 5 分 31.8

3分 31.7

2分 30.9

1分 30.6

直前 30.1

V8t. 注射

注射份

$\begin{array}{ll}\text { 2分 } & 29.6 \\ \text { 3分 } & 29.8 \\ \text { 4分 } & 29.5 \\ \text { 5分 } & 29.2 \\ \text { 6分 } & 29.0 \\ \text { 7分 } & 29.0\end{array}$

Ach. 注射

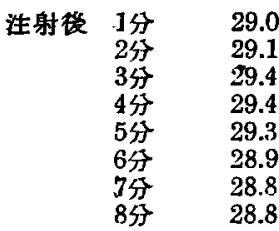

待後第 14 日

家兔 Nr. M. \&

重 $2.45 \mathrm{~kg}$.

- 室溫 $24.3^{\circ} \mathrm{C}$

耳皮府盢 ${ }^{\circ} \mathrm{C}$

注射前 2分 33.2

153 33.0

直前 33.0

Vst. 注射．

注射㣪・1分 33.0

2分

33.1

3 分

33.2

4分 33.1

5 分

33.1

9分 $\nabla テ ゙$ 每分

33.1

Ach. 注射

注射绻 1 分

$\begin{array}{ll}1 \text { 分 } & -33.2 \\ 3 \text { 分 } & 33.3 \\ 4 \text { 分 } & 33.2 \\ 5 \text { 分 } & 33.0 \\ 6 \text { 分 } & 32.9 \\ 7 \text { 分 } & 32.9\end{array}$

街第 17 日

家鬼 Nr. M. \&

鰽重 $2.5 \mathrm{~kg}$.

\section{室㳑 $24^{\circ} \mathrm{C}$}

耳皮洞溫。C

注射前 3 分 32.4

Vst. 洼射 32.4

注射桡 1 分

32.4

1,5 分

32.5

2分 $\quad 32.5$

3分 32.3

4 分 32.3

5分. 32.2

Ach. 注射

注射後 150

\begin{tabular}{|c|c|}
\hline 2分 & 32.4 \\
\hline 3 分 & 32.1 \\
\hline 4分 & $32.1^{\circ}$ \\
\hline 5 分 & 31.9 \\
\hline 6分 & 31.8 \\
\hline 分 & 31.7 \\
\hline 8分 & 31.6 \\
\hline 10 & 31.6 \\
\hline
\end{tabular}

對照例 1

徒楼第 12 日

家鬼 Nr.K. 9

鳞重 $2.6 \mathrm{~kg}$.

室溫 $21^{\circ} \mathrm{C}$

耳皮庙盢 ${ }^{\circ} \mathrm{C}$

注射前 5分 31.4

直前 30.6

Ringer 液注射

泩射後 1 分 30.4

2分 $\quad 30.4$

3行 $\quad 30.2$

4牙 $\quad 29.9$

5分 $\quad 29.9$

6分 29.8

7分 $\quad 29.8$

8分 . 29.8

Ringer 液泩射

注射啳 1 分

1分

29.7

3分

4分

5 分

6分

7 分

8分

9分

10 分

29.7

29.7

29.7

29.6

29.6

29.4

29.5

29.4

29.4

對照例 3

、正常動物

家鬼 Nr. G.

鳢重 $2.3 \mathrm{~kg}$.

室溫 $21.7^{\circ} \mathrm{C}$

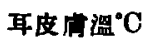

注射前 2分 32.9

直前 32.6

Ringer 液注射

注射传 1 分 $32.3^{\circ}$

2 33 $\quad 32.2$

3分 $\quad 32.2$

4 分 $\quad 32.2$

$\begin{array}{ll}5 \text { 分 } & 32.1 \\ \text { F每分 } & 32.1\end{array}$

9 分、每分， 32.1

Ringer 液注射

注射格 1分 32.1

$\begin{array}{rr}1 \text { 分 } & 32.1 \\ 2 \text { 分 } & 32.1 \\ 3 \text { 分 } & 32.0 \\ 4 \text { 分 } & 32.0 \\ 5 \text { 分 } & 31.9 \\ 6 \text { 分 } & 31.8 \\ 7 \text { 分 } & 31.8 \\ 8 \text { 8分 } & 31.7 \\ \text { 9分 } & 31.6 \\ 10 \text { 荇 } & .31 .6\end{array}$

缽照例 2

街榙第 14 日

家鬼 Nr.M. \&

触重 $2.45 \mathrm{~kg}$.

室溫 $20^{\circ} \mathrm{C}$

耳皮的盢”C

注射前 4 分 32.4

. 2 分 32.0

直前 31.5

Ringer 液注射

注射後 1分 30.9

2分 $\quad 30.8$

3分 130.8

4分 $\quad 30.7$

5分 30.8

6分 30.6

7分 30.6

8分 30.6

9分 .30 .3

Ringer 液注射

注射格 1 分 30.3

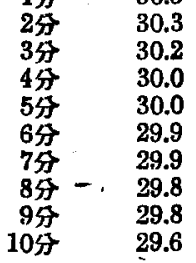




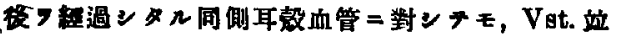

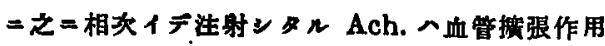
フ旺スルコト明かナ゙・

－第 3 節 總括站二考按

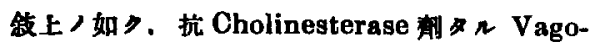
stigmin 如 二之＝相次イデ注射ンタルAcetylcho-



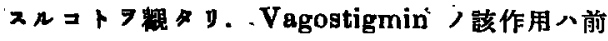
而第 1 项二於テ速ベン如ク．之が注射ニョッテ生

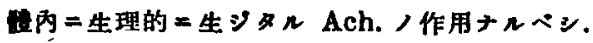

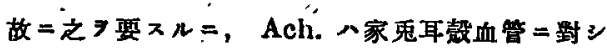

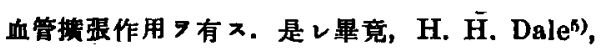



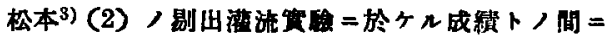
格別差違り見出スコトナカリン次第ナルガ, 生體

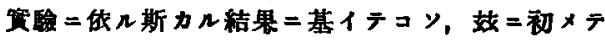

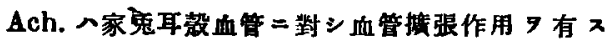

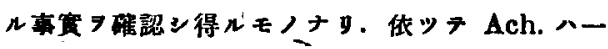

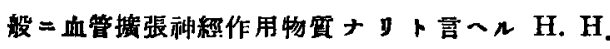

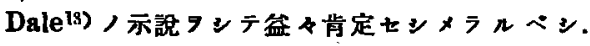

・而ンテコノ作用ハ, 前飭第2 項成精，如クAtropin ノ前處盡ニョッテ抑制をラレ、コレ亦前記先進諸 家ノ齊ンク铝メン所ト一致ン，又 Ach.八作用丧 式二於ヶネDale ${ }^{13)}$ ，所謂 Muskalin 作用郎チ副 交感神經刺戟ノ末梢作用二相賞スルコトラ示スペ $\nu$.

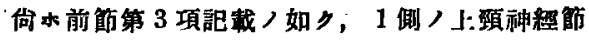



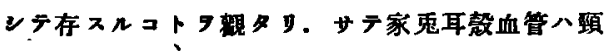
部交感神程及ビ到部神撜叢ノ第 II 及ピ第 III 頚

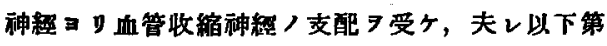

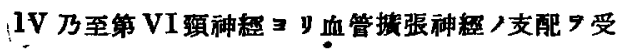
クルモノ/如ク (R. Tigerstedt(14); L. W gbràu ${ }^{15}$ )

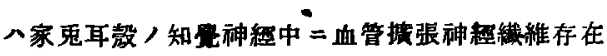
スト言へリ. 若ン然りト七ベ上影神䄳節剔出後二

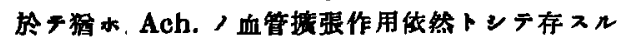
八自明ノ理 ニシテ, コノ事タルヤ末梢神释系統内

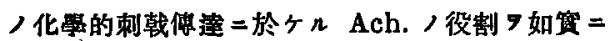

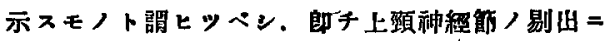

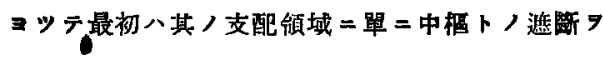
起ン，次デ前節第 3 項ノ序二記セシ如ク時日ノ經 過卜其二其ノ种悡末梢二退行性性タ來スベク，

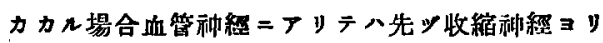

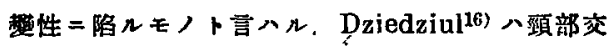

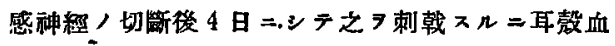
管ハ收縮二代ツテ摭张 9 起シ㭪後 11 日マデ保タ レタทト言フ.

以上ノ成紹 $=$ 於テ余八正常時ノミンラメ゙上頸神

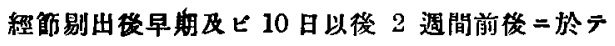

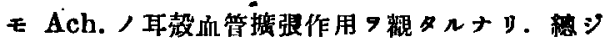

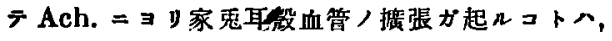


ヘトニ拘ラメ゙其ノ後神絰節㵶維ノ終末ョリ血管壁 へノ化學的刺戟傮運が所謂 "cholinergic”ナル 場合血管八撒張。起スベント䓂ヘルル Dale ${ }^{17}$ 一 派ノ所說ニ一敖スルモノト言フベン，台水上毁ノ



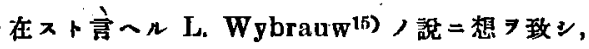

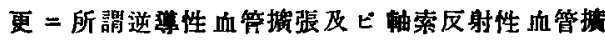

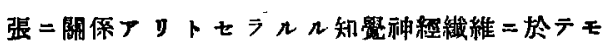

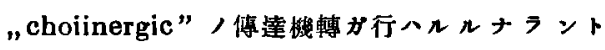
，H. H. Dale ${ }^{13)}$ ，推論 $=$ 眼 7 轉ズルトキ，血笛

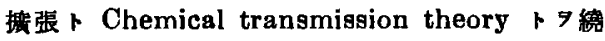
ทテ猚木今後ノ研究=俟ツペキモノアルガ如ン.

\section{第 2 華 Acetylcholin ノ犬穎下腺 血管二對スル作用 \\ 第 1 節 序 言}

额下腺血管 ヘ Clande!Bernard ${ }^{18)}(1858)=$ 依 一血管㨨镸神程，存在ガ最初二證明サレタル所=

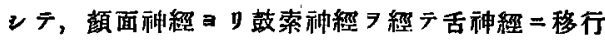

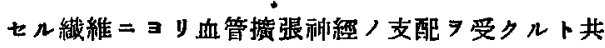
=, 频部交感神楆 3 y血管牧縮神程/支配 7 受ク

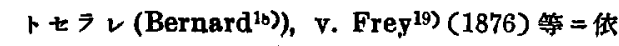




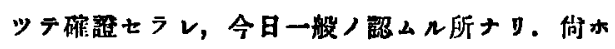

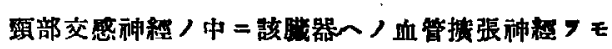
含 ムト言ㄴ (A. J. Carlson ${ }^{20)}$; A. J. Barcroft ${ }^{21)}$; C. M. Gruber ${ }^{22}$; ( (以上猫=就 $\neq$ )， R. Ge日el1 ${ }^{23)}$

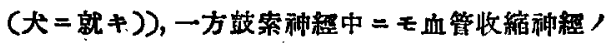

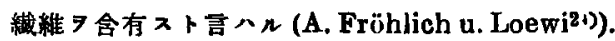



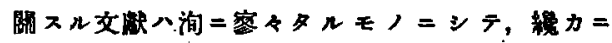
R. Hunt $\left.{ }^{6}\right)(1918)$, P. Anochin u. A. Anochina-

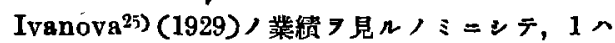
自然循環二於テ，他八淁局所血管ノ灌流ニ像ツテ，

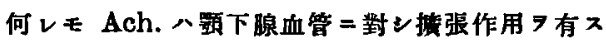

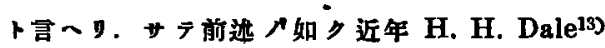

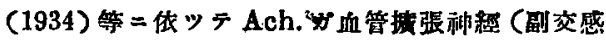

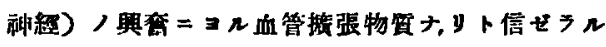

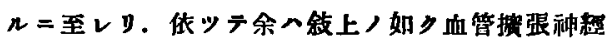

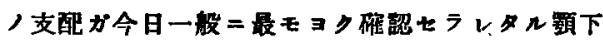
腺血管二於テ，Ach。ガ果ンテ如何ナル態度 7 取

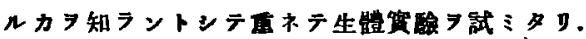
郎千疑下腺血管二於ヶル血流速度 ノ該血管二及ボス作用 9 窥七知フントセ》。血流 速度 9 测定ンテ血管口徑ノ化 9 観繁ンタれモノ

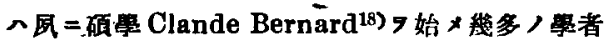
ニョッテ篇サレタィ所ニンテ，余へ以下，如キ方 法妇以テ之赛施セり。

\section{第 2 節 宽䮑方法}

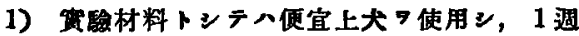
以上所定ノ小舍 $=$ テ铜蓝ン，環境＝馿致センメ其

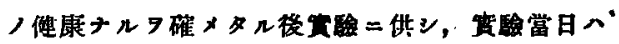
紹食センメタリ.

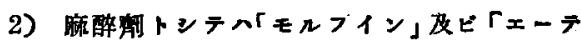
ル」＼cjkstart使用七y．H，H，Dale2のノ注意=依レパ

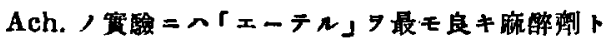

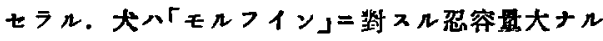
モ (H. F. O. Haberland $\left.{ }^{27)}\right)$ ，可及的少量 / 「モn

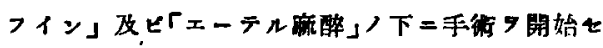
1.

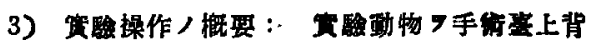
位二固定ン，前頌部二於テ先ッ正中皮切ワスレ，

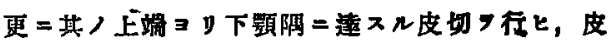

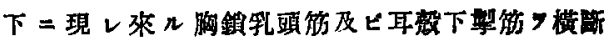
ス. 此際下＝位スル神起血管等

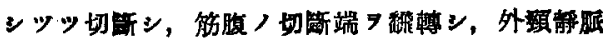

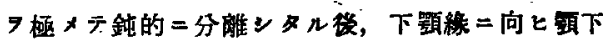
腺

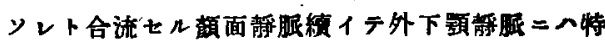

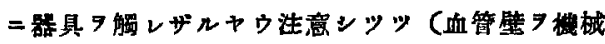
的二筇Уケルトキ細小血管二於テハ特二血梌》生

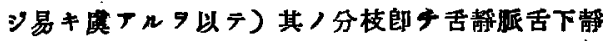

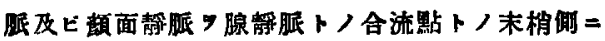

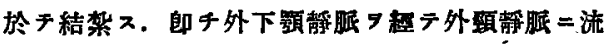

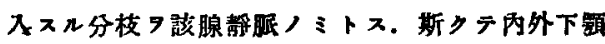

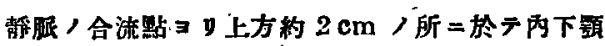

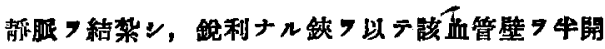

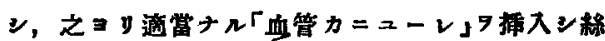
二テ結禁固定入. 而シテ其ノ「かニニーレ」ノ他端 二淁談管

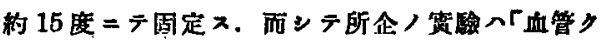

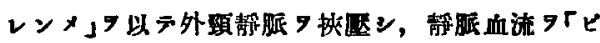
ヘット」內一流通セジ，每国「ピペットノう一定 目盛 $\exists y$ 一定盘血液 /流入スル時間 9 stop watch 7 以テ計湘七り．而ンう計测 7 終レバ血液八外頊 静脈二流入センムル、以テ循㟍血夜可フコトナ 3 .

4) 血液轻国抑制缡トンテヘNovirudin.(Norgine 化學䡆社製) 9 使用七y. Novirudin 八加

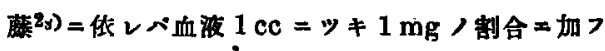
レベ完全二凝固 7 阻止ン，生體=丵ンテモ同一割

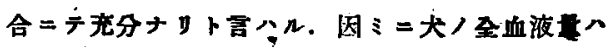

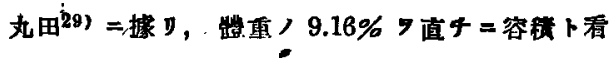
做ン；之ョリ Novirndin 溶液/必要量 7 算出亡 y. サテ余王亦 Novirudin 7 上記ノ割合 $=$ 注射 ンテ寅驗

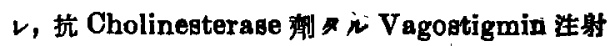




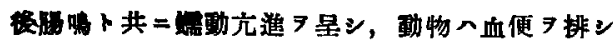

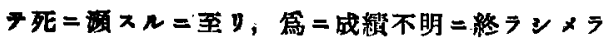

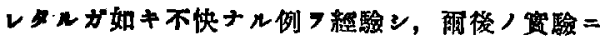
人本都ノ注射量 9 減少七y。

5) Nóvirudin 及ビ被榆菜物注射ノ点二八，血

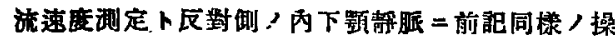

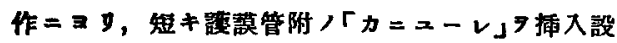
定ン，其ノ護謨管部 9 通ジテ泩入七り。

6) 敍上，如キ方法二依 リ，Vut. 及ビ Ach. 注

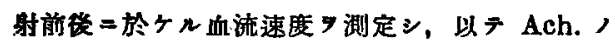

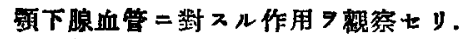

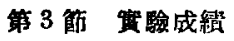

D 1 動物 Nr. 5 體重 $6.7 \mathrm{~kg}$. \&

16/X $0^{\circ} 30^{\prime}$ p. m. $2 \%$ 整酸モnフイン」2.0 cc 注射.

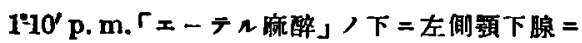
就キ筷的開始.

全血量 ca. $610 \mathrm{cc}$ トシテ，2\% Novirudin 溶液 $20 \mathrm{cc}$ 靜服注射.

$1 \mathrm{co}$ ノピ゙ット」フ用ヒテ血液 $0.5 \mathrm{cc}$ 流入 A時間 7 湘定 $邓$.

注射前 $15^{\prime \prime} 16^{\prime \prime} 16^{\prime \prime}$

Vat. $0.03 \mathrm{mg}$ kro kg $ト テ$ Vst. Ringer 氏液 9 注射

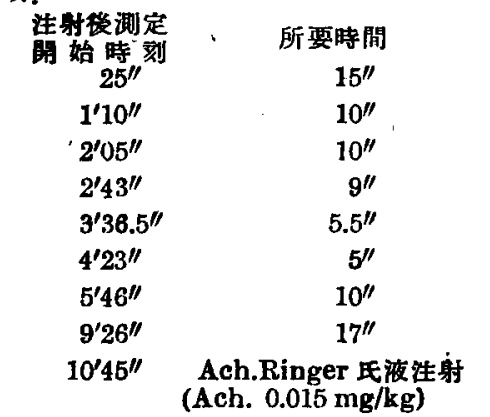

Ach: 注射後测定 所要時間

\begin{tabular}{|c|c|c|}
\hline 始 & 時刻 & $\begin{array}{c}\text { 所要時阔 } \\
16^{\prime \prime}\end{array}$ \\
\hline & $1^{\prime} 49.5^{\prime \prime}$ & $13.5^{\prime \prime}$ \\
\hline & $2^{\prime} 31^{\prime \prime}$ & $10^{\prime \prime}$ \\
\hline & $3^{\prime} 22^{\prime \prime}$ & $8^{\prime \prime}$ \\
\hline & $4^{\prime} 13^{\prime \prime}$ & $13^{\prime \prime}$ \\
\hline & $5^{\prime} 70^{\prime \prime}$ & $17 "$ \\
\hline & $7 / 31^{\prime \prime}$ & $26 \prime \prime$ \\
\hline
\end{tabular}

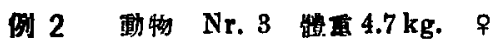

20/II $0^{\circ} 40^{\prime}$ p.m. 2\%「整酸モルフイン」1.5 cc 注射.

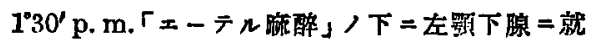
キ手術開炤.

全血量 ca. $430 \mathrm{cc} ト ン テ, 2 \%$ Novirndin 溶液 $15 \mathrm{cc}$ 注射 $x$.

$2.0 \mathrm{cc} ノ$ 「ピット」ワ用ヒテ血液 $0.2 \mathrm{cc}$ 宛流入 ス時䦓 7 測定 $ᄌ$.

注射前 :

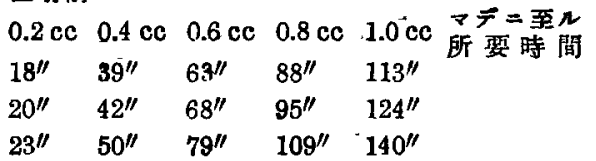

Vst. $0.01 \mathrm{mg}$ pro $\mathrm{kg}$ 注射

\begin{tabular}{|c|c|c|c|}
\hline $\begin{array}{l}\text { 注射後测定 } \\
\text { 開始時刻 }\end{array}$ & $0.2 \mathrm{cc}$ & & $0.6 \mathrm{cc} \begin{array}{l}\nabla \\
\text { 所 }=\text { 至 } \Omega \\
\text { 要時間 }\end{array}$ \\
\hline $0^{\prime} 45^{\prime \prime}$ & $35^{\prime \prime}$ & $73^{\prime \prime}$ & $118^{\prime \prime}$ \\
\hline $3^{\prime} 45^{\prime \prime}$ & $35^{\prime \prime}$ & $76^{\prime \prime}$ & $120^{\prime \prime}$ \\
\hline $8^{\prime} 50^{\prime \prime}$ & $38^{\prime \prime}$ & $82^{\prime \prime}$ & $125 " \prime$ \\
\hline $15^{\prime} 45^{\prime \prime}$ & $44^{\prime \prime}$ & $90^{\prime \prime}$ & $144^{\prime \prime}$ \\
\hline
\end{tabular}

$\begin{array}{cc}\text { Ach. 注射後測定 } & 0.2 \text { ć 流入スル } \\ \text { 開 始時剆 } & =\text { 要 スル時間 } \\ 0^{\prime} 50^{\prime \prime} & 51^{\prime \prime} \\ 2^{\prime} 10^{\prime \prime} & 51^{\prime \prime} \\ 3^{\prime} 54^{\prime \prime} & 52^{\prime \prime} \\ 5^{\prime} 25^{\prime \prime} & 51.5^{\prime \prime} \\ 10^{\prime} 50^{\prime \prime} & 57^{\prime \prime} \\ 12^{\prime} 20^{\prime \prime} & 58^{\prime \prime} \\ 18^{\prime} 50^{\prime \prime} & 65^{\prime \prime} \\ 20^{\prime} 20^{\prime \prime} & 69^{\prime \prime}\end{array}$

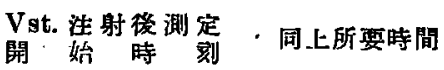

$\begin{array}{cc}0^{\prime} 58^{\prime \prime} & 67^{\prime \prime} \\ 2^{\prime} 50^{\prime \prime} & 70^{\prime \prime} \\ 4^{\prime} 47^{\prime \prime} & 70^{\prime \prime} \\ 6^{\prime} 45^{\prime \prime} & 72^{\prime \prime} \\ 16^{\prime} 10^{\prime \prime} & 78^{\prime \prime} \\ 18^{\prime} 30^{\prime \prime} \text { э y Ach. } 0.001 \mathrm{mg} / \mathrm{kg} \text { 注射 }\end{array}$

Ach. 注射後湘定

$\begin{array}{cc}\text { 開 始、時 䘞 } & \text { 同上所要時間 } \\ 1^{\prime} 02^{\prime \prime} & 65^{\prime \prime} \\ 2^{\prime} 45^{\prime \prime} & 75^{\prime \prime} \\ 5^{\prime} 23^{\prime \prime} & 70^{\prime \prime} \\ 7^{\prime} 53^{\prime \prime} & 76^{\prime \prime} \\ 10^{\prime} 40^{\prime \prime} & 80^{\prime \prime}\end{array}$

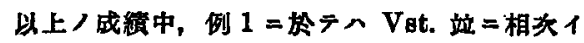




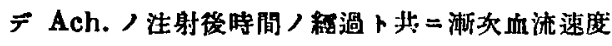

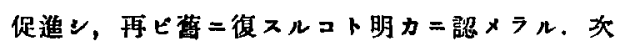
二例 2 ノ成辕 7 制定スル上二注意スペ點へ正常 時郎夫注射前既二血流速度八時閒緸過卜共=濑次

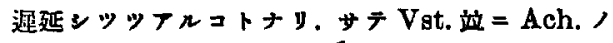
注射後 5 分前後二至ルマデノ血流速度八殆ド保合 马示セリ．是レ時閒的程過ト共 $=$ 血流速度八潮減 シッッナリト言フ资瞼條件 7 照スルトキ,コノ

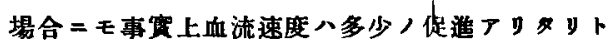
解釋スルコトフ得ベン.

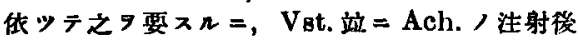

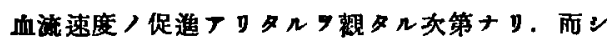
テ Vst. ノ該作用八前章訅迅ノ如ク之 䯠內 $=$ 生理的二生シタル Ach. /作用ナルベン. 由來 Ach. 八血原降下作用 7 有スルコトフ認メラ

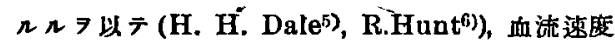

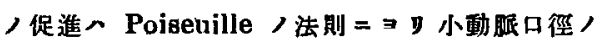

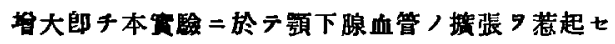
シモノト看做ン得ベン。

第 4 笘 總括站二考按

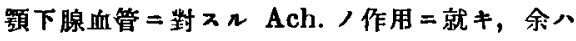

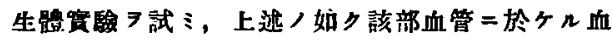
流速度人促進 =由

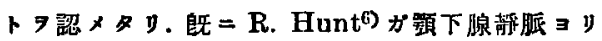
，血液增加二依 》，又 P. Anochin 等が該局所血 管ノ灌流 $=\Xi$ y, 何レモAch. 八盘管控張作用 7 是スト報告をルニ一致スル所ナり。

今以上ノ宾驗結果 $ヨ$ 些か考察 7 巡サン =, 近 年末梢神縚系統內，化學的刺戟傳造=開スル研究 ノ一部 $=$ ， V. E. Henderson \& M. H. Roepke ${ }^{30}$ )

交

1) Loewi, $O$, Pflüger's Arch., Bd. 189, $\mathrm{S}$. 239, 1921 u. folg. Bändern., Loewi, O: \&_Navratil, $E$., Pflüger's Arch., Bd. 206, S. 123 u. S. 135, 1924., v. Bd. 214 , S. 678 u. S. $689,1926$.

Dale, $\boldsymbol{H} . \boldsymbol{H}$. \& Dudley, $\boldsymbol{H}, \boldsymbol{W}$., J. Physiol., Vol.

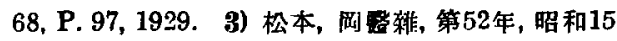
年. 4) Golte, Fr., Pflüger's Arch. Bd. 9, S. 174,
ヘ・抗 Cholinesterase 利タル Eserin タ利用ンテ


灌流腹中 $=\mathrm{Ach}$. 同一ノ生理的作用 7 有スル物

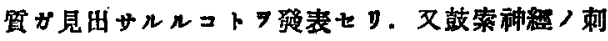
戟二依ッテ額下腺血管ノ摧張 如”Cl. Bernard ${ }^{\text {(8) }}$ 以來一般ノ諮ムル所ナy.

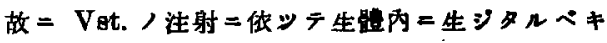
Ach. 站二相缩イテ注射セン A.ch. ガ影下腺血管 二於テ現不效果ガ鼓索种悢 9 刺戟ンタル場合卜相

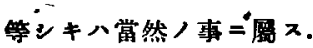



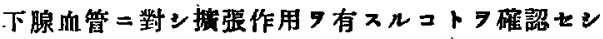
次第ナリ.

\section{第3章 結 論}

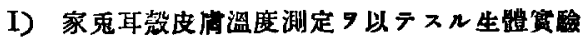
ノ結果 $=$ 农》，次ノ胡ク結諭セントス。

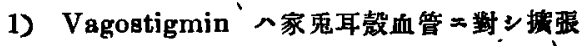
作用 $\boldsymbol{7}$ 有 $\boldsymbol{x}$.

2) Vagostigmin /前處置 $=$ 依 $y$ Acetylcholin

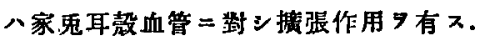

3) Atropin / 前處置 $=$ 依 y Acetylcholin', 绫作用ハ抑制をラル。

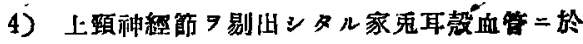
テモ，敍上ノ如キAcetylchelin /血管满張作用 八依然トンテ存ス。

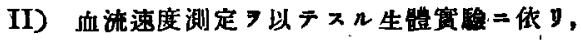
Acetylcholin 八犬颚下腺血管＝對ひ血管挴镸作・ 用 7 有スnコト7認么。

\section{蟩}

1874. 5) Dale. H. H., J. Poysiol. Vol. 48, Soc. iii, 1914., J. of Pharm. and exp.Ther. Vol. 6, P. 147, 1914. 6) Hunt, $R$., Amer. J، Phý́iol. 45,

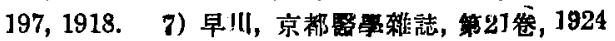

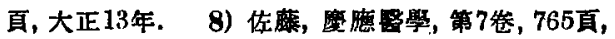
昭和2年. 9) Necheles, N., R. Frank, W. Raye, \&.E. Rosenman., Amer. J. Physiol. Volí 114, 
695, 1935-1936. 10) Dale, H. H. \& A. N, Richards, J, Physiol, Vol. 52, 111, 1918. 11) Tuckett, I. L., J. Physlol. Vol. 19, P. 291, 18951896. 12) Lapinsky, Virchows Arch. f. Path. Anratomie $1,183,1906$. 13) Dale, $H$. $H$. ., Britikh med. J. No. 3827. P. 835, 1934. 14) Tigerstedt, $R$., Phýsiolngie des Kreislaufes. IV. 1923.

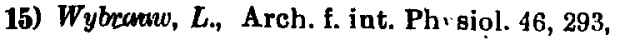
1933., zit. nach Phyaiol. Abstract. Vol. 19, 1934 -1935. 16) zit. nach Tigerstedt, $R$., oben (14) S. 200. 17) Dale, H. H., J. Physiol. Vol. 80, P. 10,1933. 18) Claude Bernard, J. de la physiol. 1. S. 651, 1858, zit. nach. $R$. Tigerstedt, oben (14) S. 202. 19) Frey, $V_{, 2}$ zit. nach. $R$. Tigerstedt, oben (14) S. 193 . Q0) Carlson, A. J., Amer. J. of Physiol. Vol. 19, P. 408, 1907. 21) Barcroft,
A. J., J. Physiol. Vol. 36, Proc. 53, $1908 . \quad$ 22) Gruber, C. M., Amer. J. Phytiol. Vol. 37, P. 259, 1915. 23) Gesell R., Amer. J. Physiol. Vol. 47, P. 496, 1919. 24) Fröhlich, A. \& Loewi., zit. nach. $R$. Tigerstedt. Oben-(14) S. 162: Anochin, 'P. \& Anuchina-Ivanova, A., Pflüger's Arch. Bd. 222. S. 478, 1929 26) Dale, H. H., J. of Pharmacol. \& exper. Ther. Vol. 6, P. 150, 1914. 27) Haberland, H. F. O., Die operative Techinik des Tierexperimentes. 28) 加藤,

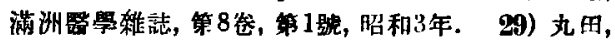

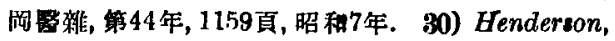
V. E. \& Roepke, M. H., J. Pharmacol. \& exper, Ther. Vol. 47, P. 193, 1933.

(昭和 17 年 7 月 15 日受稿)

Aus dem Physiologixchen Institut der Med. Falcultüt Olcayama.

(Vorstaud: Prof. Dr. S. Oinuma)

\section{Beiträge zur Wirkung des Azetylcholins auf die Gefässe.}

\section{( I. Mitteilung )}

\section{Über die Gefässwirkung des Azetylcholins bei einigen Warmblïtern.}

Vop

Nobutada Tamao.

Eingegangen am I5. Juni 1942.

Um die Gefässwirkung des Azetylcholins klarzumachen, mass der Verfasser bei der intravenösen Einspritzung von Azetylcholin und Vagostigmin die Hauttemperatur des Kaninchenohres mittels thernoelektrisches Nadels sowohl als auch die Durchströmungsgeschwindigkeit des Submaxillardrüsengefässes von Hund. Die Ergebnisse Tassen sich folgendermassen zusammenfassen.

1) Die Gefässe des Kaninchenohres wurden durch Vagostigmin erweitert.

2) Die Gefässe des Kaninchenohres wurden bei der vorläufigen Darreichung des Vagostigmins durch Azetylcholin auch erweitert.

3) Durch Atropin wurde die obenerwähnte Gefässwirkung des Azetylcholins gehemmt.

4) Die entnérvierte Gefässe des Kaninchenohres wurden durch Azetylcholin auch erweitert.

5) Azetylcholin übt einen erweiternden Ef̣fekt auf die Gefäвse der Submaxillardrüse des Hundes aus. (Aütoxeferat) 